Acta vet. scand. $1973,14,492-494$.

Brief Communication

\title{
BLOCKED UTILIZATION OF OXYGEN IN PIGS DURING EXERCISE *
}

When the oxygen consumption is insufficient for the energy expenditure during exercise blood lactic acid will increase. This is due to anaerobic breakdown of glycogen to lactic acid. The cause may be an inadequate supply of oxygen or an insufficient utilization of oxygen by the muscles.

The conventional pig is known to develop high blood lactic acid even at mild exercise. The elevation is significantly lower in pigs which have been trained by treadmill running (Lindberg et al. in press).

The present paper reports on blood oxygen, carbon dioxide, pH and lactic acid after treadmill exercise in trained and untrained pigs.

Animals and methods have been described (Lindberg et al.). Blood samples were obtained by puncturing the fibular artery (Lannek, to be publ.) or, for determination of lactic acid, the vena cava cranialis.

The results of 3 experiments are shown in Table 1. The figures represent the conditions about $5 \mathrm{~min}$. after terminated exercise.

It is seen that lactic acid is significantly higher and $\mathrm{pH}$ consequently lower in untrained pigs compared with trained animals. Lowering of $\mathrm{P} \mathrm{CO}_{2}$ corresponds to increased utilization of the $\frac{\mathrm{HCO}_{3}^{-}}{\mathrm{CO}_{2}}$ buffering system with blowing off of $\mathrm{CO}_{2}$ by lung ventilation.

It appears further that the relative anaerobosis in untrained pigs is associated with elevated $\mathrm{P} \mathrm{O}_{2}$ in arterial blood as compared with trained pigs. This supports the hypothesis that the anaerobosis is caused by blocked peripheral utilization of oxygen. Thus, the effect of training would mainly be an improvement

* Supported by Statens Råd för Skogs- och Jordbruksforskning. 
T a b le 1. Arterial blood $\mathrm{P} \mathrm{O}_{2}, \mathrm{P} \mathrm{CO}_{2}$ and $\mathrm{pH}$ and venous blood lactate in trained ( $\mathrm{T}$ ) and not trained (NT) pigs after treadmill exercise, $2.5 \mathrm{~m}$ per sec. for $4 \mathrm{~min}$. $\mathrm{P} \mathrm{O}_{2}, \mathrm{P} \mathrm{CO}_{2}$ and $\mathrm{pH}$ were calculated for $40^{\circ} \mathrm{C}$. (Number of pigs within brackets).

\begin{tabular}{lrrc}
\hline Experiment & \multicolumn{3}{c}{107} \\
\cline { 2 - 4 } & \multicolumn{1}{c}{$\mathrm{T}$} & $\mathrm{NT}$ & $\mathrm{P}$ \\
\hline $\mathrm{P} \mathrm{O}_{2} \mathrm{~mm} \mathrm{Hg}$ & $107.90 \pm 12.48(9)$ & $122.93 \pm 6.27(16)$ & $<0.005$ \\
$\mathrm{P} \mathrm{CO}_{2} \mathrm{~mm} \mathrm{Hg}$ & $26.86 \pm 3.46(7)$ & $21.57 \pm 2.46(12)$ & $<0.005$ \\
pH & $7.17 \pm 0.04(9)$ & $7.02 \pm 0.07(15)$ & $<0.005$ \\
Lactate meq./1 & $11.04 \pm 3.06(10)$ & $19.69 \pm 2.59(9)$ & $<0.001$ \\
\hline
\end{tabular}

Table 1 (continued).

\begin{tabular}{lccc}
\hline Experiment & \multicolumn{4}{c}{108} & P \\
\cline { 2 - 4 } & $\mathrm{T}$ & $\mathrm{N} T$ & \\
\hline $\mathrm{P} \mathrm{O}_{2} \mathrm{~mm} \mathrm{Hg}$ & $110.79 \pm 3.93(8)$ & $123.38 \pm 8.08(15)$ & $<0.001$ \\
$\mathrm{P} \mathrm{CO}_{2} \mathrm{~mm} \mathrm{Hg}$ & $32.63 \pm 3.29(6)$ & $27.30 \pm 2.99(9)$ & $<0.01$ \\
$\mathrm{pH}$ & $7.18 \pm 0.10(9)$ & $7.08 \pm 0.10(1.5)$ & $<0.025$ \\
Lactate meq./1 & $19.26 \pm 4.68(10)$ & $24.86 \pm 4.50(15)$ & $<0.01$ \\
\hline
\end{tabular}

Table 1 (continued).

\begin{tabular}{lrrr}
\hline Experiment & \multicolumn{3}{c}{109} \\
\cline { 2 - 4 } & \multicolumn{1}{c}{$\mathrm{T}$} & \multicolumn{1}{c}{ NT } & P \\
\hline $\mathrm{P} \mathrm{O}_{2} \mathrm{~mm} \mathrm{Hg}$ & $113.42 \pm 6.10(9)$ & $127.00 \pm 5.87(9)$ & $<0.001$ \\
$\mathrm{P} \mathrm{CO}_{2} \mathrm{~mm} \mathrm{Hg}$ & $30.36 \pm 2.69(9)$ & $26.32 \pm 1.79(9)$ & $<0.005$ \\
$\mathrm{pH}$ & $7.33 \pm 0.09(9)$ & $7.17 \pm 0.05(9)$ & $<0.001$ \\
Lactate meq./1 & $9.62 \pm 2.93(9)$ & $20.25 \pm 1.85(9)$ & $<0.001$ \\
\hline
\end{tabular}

of the capacity of the oxidative energy processes in the tissues (Holloszy 1967). The elimination of an inadequacy of the peripheral circulation cannot be excluded.

The conditions are in some respects similar to Halothaneinduced anaerobosis in pigs (Berman et al. 1970). In their experiments lactacidosis also developed in spite of high arterial oxygen tension. 
N. Lannek and P. Lindberg

Department of Medicine I,

L. Jönsson

Department of Pathology,

Royal Veterinary College, Stockholm.

G. Johansson

Department of Rehabilitation Medicine I,

Department of Clinical Physiology,

Sahlgrenska sjukhuset, Göteborg, Sweden.

\section{REFERENCES}

Berman, M. C., G. G. Harrison, A. B. Bull \& J. E. Kench: Changes underlying Halothane-induced malignant hyperpyrexia in Landrace pigs. Nature (Lond.) 1970, 225, 653-655.

Holloszy, J. O.: Biochemical adaptations in muscle. J. biol. Chem. 1967, $242,2278-2282$.

Lannek, N.: Arterial puncture in pigs. To be publ.

Lindberg, P., N. Lannek, L. Blomgren, G. Johansson \& L. Jönsson: Blood lactic acid in untrained and trained pigs under stress conditions. Nord. Vet.-Med. In press.

(Received May 28, 1973).

Reprints may be requested from: N. Lannek, Department of Medicine I, Royal Veterinary College, S-104 05 Stockholm 50, Sweden. 